\title{
Childhood Acute Myeloid Leukemia with Abnormalities of Chromosome 7
}

National Cancer Institute

\section{Source}

National Cancer Institute. Childhood Acute Myeloid Leukemia with Abnormalities of

Chromosome 7. NCI Thesaurus. Code C122726.

A rare acute myeloid leukemia that occurs in childhood and is characterized by deletion of chromosome 7. 